\title{
MATERNAL IODINE STATUS AND THYROID FUNCTION DURING PREGNANCY
}

\author{
TAHRIM MEHDI ${ }^{1}$, MD. MOZAMMEL HOQUE ${ }^{1}$, ZINNAT ARA NASREEN ${ }^{2}$, FARZANA SHIRIN ${ }^{3}$, MD. \\ MAQSUDULHAKIM KHAN ${ }^{4}$
}

\begin{abstract}
Background: Pregnant ladies are most likely to develop relative iodine deficiency during pregnancy to affect thyroid function in our population unless specific dietary care or therapeutic iodine supplementation is taken into account which is yet to be materialized.
\end{abstract}

Methods: In this cohort study sixty uncomplicated normal pregnant women were enrolled in $1^{\text {st }}$ trimester and followed up till delivery. In every trimester maternal iodine status \& thyroid status were determined by urinary iodine \& serum thyroid hormone concentration respectively.

Results: Women progressively become more iodine deficient \& tends to be hypothyroid as pregnancy advances. At $3^{\text {rd }}$ trimester of pregnancy maternal Urinary Iodine found to be negatively correlated with their serum TSH.

Conclusion: During pregnancy women develop iodine deficiency which adversely affects the thyroid function. So adequate iodine monitoring and iodine nutrition during pregnancy is necessary.

Keywords: Urinary iodine level, TSH, FT3, FT4.

\section{Introduction:}

Thyroid status is known to have an important bearing on the ability of women to conceive and to bring a normal infant to term. Both maternal hyper and hypothyroidism have deleterious effect on pregnancy out come and thyroid hormone excess has direct toxic effect on fetus. ${ }^{1,2}$

Very few longitudinal studies abroad but none in our country have considered the maternal thyroid function during the course of pregnancy in relation to maternal iodine status. Our people get iodine mainly from iodized salt provided by nationwide salt iodization program. Strict quality control \& the strict maintenance of optimum iodine content of our iodized salt is still in question. So this study has been designed to explore the iodine status \& thyroid status of Bangladeshi pregnant women used to conventional dietary practice during pregnancy .

\section{Materials \& Methods:}

In a observational cohort study through convenient sampling 80 uncomplicated nonsmoker, nonalcoholic, normotensive healthy pregnant women free from DM, renal disease, liver disease, thyroid disorder, thyroid auto $\mathrm{Ab}$, iron deficiency \& bad obstetrical history were selected for the study in their early $1^{\text {st }}$ trimester from the Gynaecology out patient department, BSMMU hospital. Ethical clearance was taken from the central ethical committee of BSMMU \& Informed written consent was taken from all study subjects preserving their rights, previlages \& freedom. Since enrollment all subjects were followed up till delivery. During follow up 20 study subjects were dropped out at different stages of pregnancy. During the total course of follow up all subjects were evaluated clinically $\&$ in $1^{\text {st }}, 2^{\text {nd }}$, $3^{\text {rd }}$ trimester of pregnancy blood were collected to assess thyroid status $\left(\mathrm{FT}_{3}, \mathrm{FT}_{4}, \mathrm{TSH}\right)$ and simultaneously spot urine was collected to assess the iodine status of pregnant women.

Thyroid hormones of all study subjects were estimated by Micropartical Enzyme Immunoassay Method with commercially available kits using AxSYM system. Urinary iodine was estimated by Sandell-Kolthhoff reaction principle. ${ }^{3}$

\section{Statistical analysis:}

All data were recorded systematically in a preformed data sheet. Statistical analysis was performed by using SPSS for windows version 12.0. Anova test, unpaired t test, pearson's correlation coefficient test $\& \chi^{2}$ test done as tests of significance. $95 \%$ confidence limit $(p<0.05)$ was taken as level of significance.

1. Department of Biochemistry, Bangabandhu Sheikh Mujib Medical University, Dhaka,

2. Department of Gynae \& Obstetrics, Shikder women's Medical College, Dhaka,

3. Department of Biochemistry, Khwaja Yunus Ali Medical College, Sirajganj,

4. Department of Cardiology, United Hospital Limited, Dhaka, Bangladesh.

Correspondence : Dr. Tahrim Mehdi, Department of Biochemistry, Bangabandhu Sheikh Mujib Medical University, Dhaka 


\section{Results and Observation:}

Table-I

Maternal urinary iodine \& iodine status at different trimester of pregnancy

\begin{tabular}{lcccc}
\hline Parameters & $1^{\text {st }}$ trimester $\mathrm{n}=60$ & $2^{\text {nd }}$ trimester $\mathrm{n}=60$ & $3^{\text {rd }}$ trimester $\mathrm{n}=60$ & Level of significance \\
\hline Urinary iodine $(\mu \mathrm{g} / \mathrm{L})$ & $143.02 \pm 25.26$ & $132.65 \pm 25.57$ & $120.48 \pm 28.7$ & $\mathrm{p}<0.001^{* *}$ \\
$\mathrm{~m} \pm \mathrm{SD}$ & $1(1.7 \%)$ & $7(11.7 \%)$ & $13(21.7 \%)$ & $\mathrm{p}<0.05^{*}$ \\
$\begin{array}{l}\text { Number of iodine deficient } \\
\text { subjects(U.Iodine }<100 \mu \mathrm{g} / \mathrm{L})\end{array}$ & & & \\
\hline
\end{tabular}

** p- value reached by one way ANOVA \& multiple comparison (Bonferroni) test.

*p-value reached by $\chi^{2}$ test.

\section{Table-II}

Maternal Thyroid hormones \& Thyroid status at different trimester of pregnancy period

\begin{tabular}{lccc}
\hline Parameters & $1^{\text {st }}$ trimester $\mathrm{n}=60$ & $3^{\text {rd }}$ trimester $\mathrm{n}=60$ & Level of significance \\
\hline TSH $(\mathrm{m} \mathrm{IU} / \mathrm{L})(\mathrm{m} \pm \mathrm{SD})$ & $2.0 \pm 1.6(6.0-7.9)$ & $3.01 \pm 1.3(0.8-7.0)$ & ${ }^{\mathrm{p}}<0.001$ \\
FT4 $(\mathrm{p} \mathrm{mol} / \mathrm{L})(\mathrm{m} \pm \mathrm{SD})$ & $12.3 \pm 2.9(7.0-24.8)$ & $9.6 \pm 1.8(5.5-14.4)$ & ${ }^{*} \mathrm{p}<0.001$ \\
FT3 $(\mathrm{p} \mathrm{mol} / \mathrm{L})(\mathrm{m} \pm \mathrm{SD})$ & $3.4 \pm 1.0(1.4-6.0)$ & $2.7 \pm 0.8(1.2-4.8)$ & ${ }^{*} \mathrm{p}<0.001$ \\
\hline
\end{tabular}

* p-value reached by unpaired t-test

Table-III

Correlation of maternal Urinary iodine (at $3^{\text {rd }}$ trimester) with serum TSH (at $3^{\text {rd }}$ trimester)

\begin{tabular}{lcc}
\hline $\begin{array}{l}\text { Dependent } \\
\text { Independent }\end{array}$ & "r" value & "p"value \\
\hline TSH vs Urinary iodine & -.242 & $<0.01^{*}$ \\
\hline
\end{tabular}

* Significant

\section{Discussion}

Gestational hyperthyroidism although uncommon, may lead to prematurity, intrauterine growth retardation (IUGR), fetal or neonatal thyrotoxicosis etc. ${ }^{4,5}$ Gestational hypothyroidism is relatively common leading to fetal \& maternal morbidities; like maternal obstetrical complications, impaired neuropsychological developments of neonates with frustrating IQ. ${ }^{4-6}$

Adequate supply of iodine is essential to maintain the normal thyroid function. It is especially important particularly during pregnancy where the iodine requirement is increased due to enhanced renal clearance of iodine, transfer of iodine from mother to fetus as well as greater need of iodine to make more thyroid hormones to support the increased metabolic demand in pregnancy. ${ }^{7,8}$ Therefore it is not unlikely for pregnant ladies to develop relative iodine deficiency during pregnancy unless specific dietary care is taken in this regard.

Since iodine is critical for normal development of baby in the womb, so for women who plan to become pregnant; iodine intake is one of the important nutritional factors they need to take into account. Mestman et al. and Ardawi et al. cautioned about low birth weight baby born to iodine deficient and hypothyroid mother. ${ }^{9,10}$

Till about twelve weeks of gestation; fetal thyroid can't concentrate iodine and depends on maternal thyroid hormones. Moreover due to increased placental deiodinase most of the maternal thyroid hormone gets inactivated in placenta \& very little get access to fetal blood to maintain early fetal brain development. After twelve weeks fetus depends largely on its own thyroid hormones but it is of course dependent on transplacental transfer of iodine from maternal blood. ${ }^{11}$

In iodine sufficient areas the physiological iodine losses that happen to be usual in pregnancy may not be associated with significant changes in maternal 
thyroid economy. Conversely in moderately or marginally low iodine intake areas pregnancy leads to relative iodine deficiency state as indicated by relative hypothyroxinemia, increased serum TSH concentration and increased maternal thyroid volume. ${ }^{11}$ However in severely iodine deficient areas, the changes are more pronounced accompanied by intense maternal \& neonatal thyroid stimulation. ${ }^{13,14}$

Glinoer \& his coworkers also found marginal hypothyroidism during pregnancy even in iodine sufficient area that is amplified when there is iodine restriction or overt iodine deficiency and the maternal iodine deficient status leads to goiter formation in progeny with neuropsycho-intellectual impairment that is preventable by iodine supplementation during pregnancy. ${ }^{15}$ Even a sub clinical iodine deficiency in pregnancy associated with poor cognitive outcome in children ${ }^{16}$ and adversely affects the thyroid function of mother and newborn with increased risk of mental retardation in offsprings. ${ }^{17}$

Peoples living in areas affected by severe IDD may have an IQ of up to 13.5 point below the IQ of those from areas without iodine deficiency. This mental deficiency has an immediate effect on child learning capacity, women's health, quality of the life of communities and economic productivity. ${ }^{18}$

In this study pregnant women found to be iodine deficient progressively with advancing gestational age probably because of the failure of adequate dietary iodine intake particularly in advanced pregnancy. This could be due the nonappetizing and anorexic problems incident to the pathophysiological changes during pregnancy. These results are consistent with many other reports done abroad. ${ }^{19-25}$ However our result contrasted with some other reports showing urinary iodine concentration either increased ${ }^{26}$ or unchanged ${ }^{27}$ during pregnancy as compared with non pregnant values. These differences could be explained by the existence of urinary iodine threshold called iodostat; the level of which is set by the customary dietary iodine practice of community concern. In pregnancy, the iodostat may not change to conserve iodine despite the enhanced urinary iodine excretion. The latter may result in depletion of thyroidal iodine stores culminating to deleterious effects for both mother and neonates particularly if iodine intake during gestation is inadequate.

In the present study we observed the thyroid hormones (serum $\mathrm{FT}_{3}, \mathrm{FT}_{4}$ ) to be decreased and serum $\mathrm{TSH}$ to be increased significantly in $3^{\text {rd }}$ trimester of pregnancy compared to $1^{\text {st }}$ trimester. Our study clearly documented the changes in urinary iodine excretion and in thyroid hormones during the course of pregnancy. These changes involving $\mathrm{FT}_{3}, \mathrm{FT}_{4} \mathrm{TSH}$ \& urinary iodine are well harmonious with the speculated iodine deficiency and the consequent low thyroidal activity during normal pregnancy. Some studies on the changes of $\mathrm{FT}_{4} \& \mathrm{FT}_{3}$ level during pregnancy have shown conflicting picture with some showing an increase and in others no change at all ${ }^{30}$. These discordant results can be partly related to the methodologies employed and the studied population ${ }^{31}$. Few sporadic studies on the changes of serum TSH concentration during the course of pregnancy found conflicting with respect of ours. These reported unchanged ${ }^{32,33}$ or slightly increased TSH level ${ }^{34}$. These contradictory results are also party explained by the methodologies employed and probably by the baseline iodine status of the population studied ${ }^{7,31}$.

This study suggests the measurement of serum thyroid hormone and urinary iodine in all pregnant women as a part of routine antenatal check-up \& thereby their monitoring \& management needs to be done in antenatal period.

\section{References}

1. Anseimo J, Cao D, Karrison T, Weiss RE, Fefetoff S. Fetal loss associated with excess thyroid hormone exposure. JAMA. 2004; 292: 691-5.

2. Potter JD, Mc-Michael AJ, Hetzel BS . Iodinization and thyroid status in relation to still birth \& congenital anomalities. Int J Epidemol. 1979; 8:13744.

3. WHO. UNICEF. ICCIDD. Progress towards the estimation of IDD. WHO booklet Geneva. WHO. 1999: 1-33.

4. Lazarus JH, Premawardhana LD. Screening for thyroid disease in pregnancy. J Clin Patho 2005; 58: 449-52.

5. Karabinas CD, Tolis GJ . Thyroid disorders \& pregnancy. J Obstet Gynaecol 1998; 18: 509-15.

6. Rodien P, Coutant R, Vasseur C, Bourdelot A, Laboureau S, Rohmer V. thyroid dysfunction \& pregnancy. Rev Prat 2005; 55: 174-9.

7. Lazarus JH, Kokandi A. Thyroid disease in relation to pregnancy. Clin Endocrinol. 2000; 53: 265-78.

8. Glinoer D. Maternal and foetal impact of chronic Iodine deficiency. Clin Obstet Gynaecol 1997; 40: 102-116. 
9. Mestman J, Goodwin TM, Montoro MM. Thyroid Disorders of Pregnancy. Endocrinol Metab clin N Am 1995; 24: 41-71.

10. Ardawi SM, Nasrat HA, Mustafa BE. Urinary Iodine excretion and maternal.Thyroid function during pregnancy and postpartum. Saudi Med J. 2002; 23(4): $\quad 413-22$.

11. Greenspan FS The thyroid gland. in: Greenspan, FS, Gardner, DG (eds), Basic and clinical endocrinology 2004;p:215-294.

12. Glinoer D, De Nayer P, Bourdoux P, Lemone M, Robyn C Van, Steirteghem, A, et al. Regulation of maternal function during pregnancy .Clin Endocrinol Metab. 1990; 72: 276-87.

13. Silva JE, Silva S . Interrelationships among serum T4, T3, rT3 \& TSH in iodine deficient pregnant women \& their offspring effects of Iodine supplementation. Clin Endocrinol Metab 1981; 52: 671-7.

14. Thilly $\mathrm{CH}$, Delange F, Lagasse R, Bourdux P, Ramioul L, Berquists $\mathrm{H}$ et. al. Fetal hypothyroidism \& maternal thyroid status in severe endemic goiter. Clin Endocrinol Metab. 1978; 47: 354-60.

15. Glinoer D. Pregnancy \& Idoine Thyroid 2001; 11: 471-81.

16. Choudhury N, Gorman KS. Subclinical prenatal iodine deficiency negatively affects infants development in Northern China. J Nutr 2003; 133 : 3162-5.

17. Zimmermann $\mathrm{M} \&$ Delange $\mathrm{F}$ Iodine supplementation of pregnant women in Europe: a review. Eur J Clin Nutr. 2004; 58: 979-84.

18. Bleichrodt N, Born MA. Meta analysis of research on Iodine and its relation to cognitive development. In : Stanbury JB (ed). The damaged brain of Iodine deficiency. 1994; 195-200.

19. Azizi F, Aminorryo A, Hedayatin M, Rezvanian H, Amini M, Mirmiran P. Urinary Iodine excretion in Pregnant Women residing in areas with adequate iodine intake. Public Health Nutrition 2002; 6: 95-98.

20. Eltom A, Eltom M, Elnagor B, Elbagir M, GebreMedhim M . Changes in Iodine metabolism during late pregnancy and lactation: a longitudinal study among Sudanese women. EJCN. 2000; 54(5): 42933.

21. Glinoer D, De-Nayer P, Delange F. A randomized trial for The treatment of Thyroid Stimulation in pregnancy: maternal and neonatal effects. J clin Endocrinal Metab 1995; 80: 258-69.
22. Pathak P, Singh P, Kapil U, Reghuvanshi RA . Prevalence of Iron, Vit-A and Iodine deficiency amongst adolescent pregnant mothers. Indian J Pediatr. 2003; 70: 299-301.

23. Caron P, Hoff M, Bazzi S, Dufor A. Urinary Iodine excretion during normal pregnancy in healthy women living in the South West of France: correlation with maternal thyroid parameters. Thyroid. 1997; 7(5): 749-54.

24. Dunn JT what's happening to our Iodine. J Clin Endocrinol Metab. 1998; 83: 3398-400.

25. Pedersen KM, Laurberg P, Iversen E, Knudsen PR. Amelioration of some Pregnancy associated Variations in Thyroid function by Iodine supplementation. Clin Endocrinol Metab. 1993; 77: 1078-83.

26. Elnagar BEA, Wide L, Gebre-Medhim M, Karlson FA. Iodine status \& Thyroid function \& Pregnency. Eur J Clin Nutr 1998; 52: 351-55.

27. Smyth PPA. Variation in Iodine handling during normal pregnancy. Thyroid 1999; 9: 637-42.

28. Kapil U, Pathak P, Singh C, Tandom M, Pradhan R. Micronutrients deficiency disorders amongst pregnant women in rural slum communities of Delhi. Indian Pediatrics . 1999; 36: 793-6.

29. Chakraborty I, Chatterjee S, Bhadra D, Mukhopadhaya BB, Dasgupta A, Purkait B. Iodine deficiency disorders among The Pregnant women in a rural hospital of West Bengal. Indian J Med Res 2006;123: 825-29.

30. Smyth PPA, Hetherton AMT, Smith DF, Radeliff,M, Otherlihy C. Maternal Iodine Status and thyroid Volume during pregnancy: Correlation with neonatal Iodine intake. J of clin Endocrinol and Metab1997; 82(9): 2840-3.

31. linor D, De-Nayer P. Thyroid \& its disease in pregnancy. In: Monaca F, Satta MA, Shopiro B, Troncon L. Thyroid diseases clinical fundamental therapy. Newyork, CRP press. 1993; 517-27.

32. eeke J, Dybkjaer L, Granlic K. A longitudinal study of Serum TSH, $\mathrm{T}_{3}, \mathrm{~T}_{4}$ During normal pregnancy.Am J obstet G ynecol, 1982; 160: 1216-20.

33. asmussen NG, Hornnes PJ, Hedus L, Ultrasonically determined Thyroid size in pregnancy postpartum. Am J Obstet Gynecol. 1989; 160: 1216-20.

34. urrow GN.Thyroid status in normal Pregnancy, Clin endocrinol Metab 1990; 71: 274-5. 